\title{
Al-Imam Al-Ghazali’s View of Moral Education: Its Purposes and Pillars
}

\author{
Mohammed Hassan Al-Awamreh \\ Al-Zaytoonah Private University, Amman, Jordan
}

\begin{abstract}
The objective of this research is to discuss Al-Imam Al-Ghazali's concept of moral education: purposes and pillars through using the deductive and inductive methods. According to Al-Ghazali, morals have two sides: instinctive and acquired. As for Al-Ghazali, moral education aims to achieve some goals that work to promote the moral, intellectual, and social level of individuals and the whole society. On the other hand, the most important pillars of moral education are considering individual differences, accountability, self-monitoring, learning by practice, gradual education, perseverance, self-purification, and reinforcement. The study concludes that Al-Ghazali differentiates between the morals as a nature and distinct, and good manners.
\end{abstract}

Keywords: moral education, good manners, Al-Imam Al-Ghazali, purposes, pillars

\section{Introduction}

The issue of educational thought, along with its message for civilization, is considered one of the main challenges that many Arab countries face since it is an undisputable fact. The fate of the people and generations depend on how effective the educational system is in making the good humans and providing them with values and positive attitudes, different thinking skills, as well as concepts. These all will equip them with the opportunity to cope up with the changes and challenges that face them in the field of digital and knowledge revolution.

The Islamic educational thoughts represent the intellectual excellence found in the holy Quran and Sunnah within the educational literature that comes in the form of books, commandments, or extracts of different Islamic writings and masterpieces. Those writings were composed by thinkers who were specialized in some educational aspects or other aspects of knowledge. The educational thought is defined as a set of concepts, visions, and educational perspectives that are derived from the holy Quran, Sunnah, as well as the scholars' personal judgments that are congruent with the spirit of Islam (Al-Rashdan, 2004).

Educational thought is a real reflection of its era in all fields. Those are interested in the educational thought in the Arab countries, even when they talk about some manifestations of the crisis, they rarely exceed that to the real thought (Ahrashu, 1998). Among the scientists whose scientific impact has contributed to mankind until this day is Al-Imam Al-Ghazali. He had several impacts on various fields, such as the interpretation of the holy Quran, prophet Muhammed's sayings, theology, jurisprudence, Sufism, etc.. Al-Ghazali tried to revive religion in people's souls when he called for educating oneself and taming it by morals.

Al-Ghazali is Imam Zein El Deen Abu Hamed Mohammad Bin Mohammad Bin Ahmad Al Tousi Al Shafie Al-Ghazali. He was born in 450 Hijri (1058 AD) in Tous—one of Khourasan’s provinces in Persia—and died in

Mohammed Hassan Al-Awamreh, Ph.D., assistant professor, Humanities Department, Al-Zaytoonah Private University. 
Toubran, the capital of Tous, in 505 Hijri (1111 AD). He is considered as one of the greatest Muslim thinkers and defenders. He was also Soufi, jurisprudent, and debater. Al-Ghazali was known as the argument of Islam since he stood up against its adversaries.

Al-Ghazali was one of the well-known Islamic educational thought scholars who had a leading role in education and reformation that was based on the main recourses of legislation (Quran and Sunnah). Al-Ghazali paid special attention to the moral education and discipline. He addressed morals in most of his books, such as: Ihyaa' Ulum Al-Deen (Revival of the Religious Sciences), Al-Munqidh min al-Dalal (Rescuer from Misguidance), Tahafut Al-Falasifah (The Fall of Philosophers), Al-dorra al-Fakhira (The Precious Pearl), Mukaashafat Al-Quloob (Revealing What Is in Hearts), Minhaaj-ul-Aabideen (The Path of the Worshippers), Bidayat Al-Hidaya (The Beginning of Guidance), Al-Ajwibah Al-Ghazaliyyeh (Al-Ghazali's Answers), Al-Masa'el Al-Ukhrawiyyeh (The Hereafter Questions), Mahak Al-nathar (Touchstone of Reasoning), Al-maqșad al-asaniy (The Best Means), Al-Hikmah fi makhlooqat Allah (Wisdom in God's Creation), Al-Iqtisad fil I'tiqad (Divine Predicates and their Properties), Iljam Al-'Awam (Control of the Public), Al-Mustasfaa min'ilm al-usul (On Legal theory of Muslim Jurisprudence), Aadaab Al-Sofiyyeh (Sofism Rules), Al-Kashf wal Tabyeen (Revealment and Epiphany), Kimyaa' Al-Sa'adeh (Chemistry of Happiness), Jawaher Al-Quraan (Jewels of the Quran), Ayyuha l-Waalid (My Dear Parent), Mishkat Al-Anwar (The Niche for Lights), Risaalat Al-Tayr (Epistle of the Bird), Al-Risalah al-Wa'dhiyah (Exhortation messages), Al-Jawaher Al-Ghawali wal Qusoor Al-'Awali (Priceless Jewels and the lofty palaces), and Al-Murshed Al-Ameen fi Maw'ithat Al-muttaqeen (The Honest Guide for Exhorting Pious People).

Ibn (1981) saw that good manner is an inner power leading for its actions without thinking or patience. This power is divided into two parts: (a) natural which is derived from the mood; and (b) acquired, through habit and practice. The origin of these manners could start from thinking and patience, then the person keeps doing it until it becomes a moral. Yaldgen (2003) defined good manner as:

The science of good and evil, beauty and ugliness. It has its rules, which are determined by revelation, and intended to organize the human life and determine his relationship with others in a way that perfectly achieves the purpose behind his existence. (p. 18)

Nevertheless, Al-Bagha (1981) pointed out that "a good manners is an independent character, whether natural or acquired, which has commendable or denounced effects on behavior.” However, Khisha (1991) believed that good manners are the values that are determined by religion to organize the human behavior in a way that achieves his destination and happiness in life. Therefore, good manners only include what is beautiful and commendable to the Lord and to humans.

Within the definitions of morals, some researchers considered the definition as nature and instinct, other definitions focus on morals as a visible behavior, while a third group of definitions considered it as the general view of good and evil but within norms and standards. Yet, some restricted morals in noble virtues and values. From Al-Ghazali's standpoint, a moral is the psyche and one's inner image whereas the virtue is a middle point between two denounced vices. Alternatively, it is the balance of the four self powers: anger, lust, wisdom, and justice (Nassar, 1998).

\section{Methodology}

The research adopts the inductive and deductive methods to achieve its purposes. 
The research problem lies in studying the landmarks of Al-Imam Al-Ghazali's educational thought since he is considered one of the eminent scholars that have major contributions to educational thoughts in general and to the Islamic educational thought in specific. His educational thought, derived from the holy Quran and Sunnah, had a reflection on moral upbringing of the youth and on the individual's development, so as to cope with the current age. The study tries to answer the following questions:

1. What is Al-Imam al-Ghazali's concept of moral education?

2. What are Al-Imam al-Ghazali's purposes of moral education?

3. What are Al-Imam al-Ghazali's pillars of moral education?

The goals of the study lie in identifying Al-Imam Al-Ghazali's concept of moral education as well as the purposes and pillars of moral education.

\section{Results}

\section{What Is Al-Ghazali's Concept of Moral Education?}

The greatness of Islam lies in the fact that it is not just a theoretical doctrine and mere physical worships, rather it emphasizes the association of faith and worships on one's behavior. Islam directs and controls behavior in a way that suits Islamic noble concepts, and the splendor of the divine legislation, hence, limiting the spread of moral crisis in the family, education, working area, markets, media, communication, and other fields that are mostly lacking morality.

The writings of Al-Ghazali about morals and his own concept of morals were affected by life and the way Al-Ghazali was raised taking into consideration that he wrote most of his writings after his illness, and after he was obliged to leave Iraq, and his going back to Al-hijaz as a pilgrim. In the end, he settled in Tous where he stayed in his house until his death. During this isolation, he wrote several writings about morals. Those writings were influenced by a lot of things, such as the Sufism that he inherited from his father and the 10 years spent of solitude. These had their effects on his psyche and his mood, hence, influencing his writing. Al-Ghazali sees good manners as "a well-established behavior that drives the person to act without thinking" (Al-Azzam, Matalqa, \& Rabab’a, 2014).

Al-Ghazali defined good manners as "the renovation of three forces: the power of thinking, the power of lust, and the power of anger." In another position, he defined it as "doing what a man dislikes" in congruence with the verse (But perhaps you hate a thing and it is good for you, and perhaps you love a thing and it is bad for you) (Al-Baqarah:216). Good manners are also seen as "removing all bad habits that Islamic legislation has detailed." Man, thus, refuses it since he feels disgusted of doing it just as he feels disgusted of rubbish. On the other hand, he gets used to good manners and longs for doing them, hence, these manners become part of him (Al-Ghazali, 1986).

Al-Ghazali differentiates between morals as a nature and habit, and good manners. He mentions in The Revival of Religion Sciences that if the deed created good commendable actions, by mind and by Islamic law, the deed is called good manners, and if it led to unacceptable actions, then it is called bad manners. Morals are not doing good or bad deeds, neither are they the ability to do good or bad deeds; rather, it is the deed that gives the urge to the human soul to give or to hold. Manners, as Al-Ghazali believes, are the reflection of the soul and its inner image (Al-Ghazali, 1986).

Al-Ghazali classified morals as commendable or disreputed. Yet, good manners involve avoiding bad behavior and preferring good deeds to wicked ones. Morals, from his point of view, have an instinctive side, and 
a side that can be acquired by nurturing. This means that morals have its own means and methods and requires persistence and practice. Al-Ghazali was highly affected by Sufism's moral education. Such a relationship is manifested through having common bases. We can understand how Al-Ghazali was influenced by Sufism by the following: "Sufism is having good manners when dealing with people and integrity when it comes to honesty" (Al-Sahrordi, 1966). It is also said that "whoever has morals has the greatest values” (Al-Qushayri, 1990).

Al-Ghazali sees that the process that lead to virtuous moral education is "only the Sufi approach that combines between Islam and its practices, and combines between truth and behavior, between the thinking of the mind and insight and between knowledge of science and certainty” (Barakeh, 1983).

\section{What Are Al-Imam Al-Ghazali's Purposes of Moral Education?}

For Al-Ghazali, moral education aims to achieve some of the purposes that collaborate to raise the moral, intellectual, and social levels of individuals and society. Some of these are the following:

1. Pleasing the Lord: Al-Ghazali called for working hard to please the Lord and feeling that he watches us in public and in private. Al-Ghazali also urged Muslims to revive Islamic legislation and to get closer to the Lord by following his commands and avoiding his prohibitions.

2. Creation of a balanced personality: With regard to moral education, Al-Ghazali concentrates on taking care of all sides of the human personality: The spiritual, psychological, and mental sides in all stages of growth. He emphasizes that the educational methods that work to achieve this integration and balance are resisting one's evil thoughts, doing sports to purify the heart and soul, meditation to develop the mental abilities and promote the human soul in the field of perception, as well as playing to renew the activity of the mind and senses.

3. Self-discipline: Al-Ghazali sees that self-discipline does not mean to oppress or uproot one's instincts and natural tendencies since this would be contrary to the human's nature. Instincts and lusts were not born for no reason, but for useful functions that one cannot let go of. They are intended to protect people and conserve mankind. This can be achieved through providing eating, drinking, and housing. Preserving of mankind, on the other hand, is achieved through controlling sexual desires through marriage and starting a family to conserve mankind. Al-Ghazali sees the importance of disciplining these instincts and lusts and linking them to chasity, modesty, and mind.

4. The elevation of the human psyche: Elevation of the human psyche that can be accomplished through avoiding doing deeds that belittle oneself and submitting to lusts. On the contrary, one can elevate himself/herself by worshiping the Lord and getting closer to Him by worshiping Him and doing good deeds to reach the highest levels of the human perfection (Ibrahim, 2012).

Al-Ghazali sees that the human psyche is not good nor prone to do evil. It is blank that good and evil can be engraved in it since the human psyche is willing to do either good or bad. This indicates that it is neither good nor bad but it is ready to do either of them. Al-Ghazali emphasizes that by saying:

The psyche can be good or bad by either following desires or by withholding and disobeying them. Accordingly, if a person follows his/her desires and become overwhelmed by them, he/she would become bad-mannered. However, if he/she fights and resists his/her desires, they would become good-mannered. (Al-Ghazali, 1986, p. 112)

The holy Quran pointed that the human behavior susceptible to reforming and adjustment. The individual can be morally raised, he/she can modify his/her undesirable behavior and enhance the desired behavior. It is worth mentioning that the Islam opens the doors for sinners to repent, and give them a chance to get back to the Lord's law. If the morals were not subject to change, replacement, discipline, or civility, a lot of the sermons, 
commandments, orders, and the prohibitions would become void. Moreover, many of Islam's calls for good manners would be meaningless. The prophet Mohammed—peace upon him—says, "There is nothing heavier in the believers scales on the of day judgment than good manners" (narrated by Al-Tarmathi).

According to Al-Ghazali, the purposes of moral education can be summed up as follows:

1. Seeking closeness to Almighty Lord;

2. Balancing between loving the hereafter and abandoning worldly life;

3. Achieving human happiness in the hereafter;

4. Self-cleansing and equipping the soul with virtue and good morals.

\section{What Are the Pillars of Moral Education From Al-Ghazali's Point of View?}

By analyzing his writings, the researchers conclude that Al-Ghazali set the following pillars for moral education:

1. Taking individual differences into account: Al-Imam Al-Ghazali realized that children are not equal in their tendencies and he was aware of the factors affecting these tendencies. Therefore, while raising his students, Al-Ghazali would not neglect the shy. Instead, he was trying to treat their shyness and take that as an aid to discipline them. He also studied each child's case individually and helped them according to what he sees fit (Al-Ibrashi, 1969).

Al-Imam Al-Ghazali categorized his students according to the moral diseases that they had. He studied each category separately, and put a specific treatment for each disease. He believes that moral diseases are like physical diseases; they should not all be treated using a single treatment (Al-Ghazali, 1969).

Regarding the educational material, Al-Imam Al-Ghazali has counted on the variety of the material according the abilities of learners, their needs, and their educational level (Mubarak, 1988).

2. Accountability and self-observation: Al-Ghazali focused on self-accountability in order to create inner motive which is the true guarantee to obtain good morals. In addition, it reassures self-confidence and that is why Al-Ghazali focused on finding a heart connected to the Lord that functions as the safety valve to control all human powers to be balanced in all matters (Al-Ghazali, 1986).

Thus, Al-Imam Al-Ghazali focused on the idea that the individual needs to isolate and remind himself/herself of reward and punishment, heaven's bliss, and hellfire. This will, then, become a motive towards balance, and following the mind and the Islamic legislation, hence correcting oneself (Al-Kilani, 1978).

3. Adopting gradual education: Al-Imam Al-Ghazali sees that the educator has to gradually transfer the human soul from bad morals to good morals (Hasan, 1947). That is what Al-Imam Al-Ghazali used to do with his students to discipline their behaviors. He would guide them through steps and ascend the moral educational ladder in stages. He would not take his student one step forward unless the previous step had been grounded, and if he achieved that. When Al-Ghazali was assured that the student mastered that step, he would move to the next step.

This method applies to the intellectual elevation; Al-Imam Al-Ghazali believed that that can beachieved in stages, starting from the sense range to the sanity range, then to the meditation range, and finally to the discovery range. He believed that eliminating a behavior and instilling another, to become a habit, needs to be done gradually, so that the human psyche can absorb it slowly in order to become a part from an individual's personality and subsequently acts only in light of his inner guidance (Al-Ghazali, 1934).

4. Purification and resisting one's desires: Al-Imam Al-Ghazali sees that elevating the human's psyche to high levels of perfection needs honest training and resisting one's own desires (Al-Ghazali, 1934). 
Al-Imam Al-Ghazali assures that purifying the human psyche from the desires, especially love of money, and getting rid of the stinginess only occurs when one fights against and controls the deeply-rooted innate self-desires (Al-Ghazali, 1986).

He also believes that the prophets-peace be upon them—-who are our model examples in education, resisted themselves and their reality hard in order to take their psyches from normal levels to the human perfection level, hence winning happiness. This is the path that, as Al-Ghazali thinks, the people should follow to win true happiness (Al-Ghazali, 1934).

5. Learning by hard work: Al-Imam Al-Ghazali emphasized the importance of knowledge and hard work to elevate the human psyche. He does not find it possible to separate them, rather he counts that as one of the main values of moral education (Al-Ghazali, 1970).

Al-Ghazali also emphasizes that happiness cannot be achieved for the human psyche without the association of hard work and knowledge sine that results in behavior change (Al-Kilani, 1978).

The association of knowledge and hard work seems to be a practical implementation of Islam and the Islamic morals in congruence with the verse (Or you who have believed, why do you say what you do not do ? (2) Great is hatred in the sight of Allah that you say what you do not do) (The holy Quran: AlSaff 2,3).

6. Enhancement: People like to be praised and given some credit for their good deeds. The ones who deserve complimenting and praising most are children and young people provided that they say the right thing, answer correctly, and carry out their work in a way that deserves encouragement and reward. This is exactly what is called enhancement.

The educator should be strict with pupils, because it is his responsibility to discipline them to do the right things and avoid the bad things. He also presses them to do the good deeds and guides them for what benefits them as long as it does not deviate from the framework of mercy and compassion. That is the notion of punishment.

Al-Ghazali sees that rewarding students for positive education practice enhances it. In addition, being patient in applying a punishment gives them the chance to correct their mistakes by themselves which, in turn, leads to a sense of appreciation and responsibility as well as increasing self-confidence. Moreover, it makes them happy. On the other hand, Al-Ghazali was very hesitant to use punishment (Hasan, 1947).

Al-Imam Al-Ghazali stresses on avoiding punishment and scolding as much as possible, resorting to entertainment and reward methods to prompt students to do good deeds, and drawing their attention to the dangerous consequences of bad deeds. That is more effective and leaves deeper impact in the soul (Al-Abrashi, 1969).

\section{Conclusions}

In view of what the researcher has reached through inducting and deducting Al-Ghazali's writings, the researcher has come to the following results:

1. Morals have two sides: innate and natural, which means that there are individual differences in the moral level. There is also an acquired side which indicates that the individual can be educated morally and his behavior can be adjusted towards the desired target moral.

2. From Al-Ghazali's view, the purposes of moral education can be summarized in getting closer to the Lord, balance between preferring the hereafter and getting away from the earthly life, achieving the hereafter happiness for human beings, self-purification and coating oneself with virtue and morals.

3. Al-Ghazali assured the principles of respecting individual differences, accountability, self-observance, learning by hard work, having gradual learning, resisting one's bad thoughts, self-purification, and enhancement. 


\section{References}

Ahrashu, A. (1998). Al-Fikr Al-Tarbawi Al-Mu'aser, Muqawwimatuh w khasa'isuh w Tafa'ulatuh min manthoor 'Aalami (Contemporary educational thought, pillars, characteristics and interactions from a scientific perspective). Fas, Tunisia: Al-Munathama Al-Arabiyyeh lil tarbiyah w Al-Thaqafa wal Uloom.

Al-Azzam, N., Matalaqa, A., \& Rababa’a, E. (2014). The moral education in Al-Ghazali’s view and its relationship with Sufism and contemporary applications. Al-Manara Journal, 1(20), 445-464.

Al-Bagha, M. (1981). Nitham Al-Islam (System of Islam). Damascus: Al-matba’a Al-ta’awuniyya.

Al-Bukhari, M. I. I. (2004). Saheeh Al-Bukhari (Al-Bukhari collection of the prophet’s sayings). Al-Riyadh, maktabet El-Rushd Nasheroon.

Al-Ghazali, M. B. M. (1969). Al-Murshid Al-Ameen ila Maw'ithat Al-Muttaqeen (The honest guide to the sermon of the pious) (3rd ed.). Cairo: Mustafa al Halabi and Sons Press.

Al-Ghazali, M. B. M. (1978). Al Ghawali min Rasa'el Al- Imam Al Ghazali (The precious jewels from imam Al-Ghazali epistles). Baghdad: Maktabat Al-Sharaf Al-Jadeed.

Al-Ghazali, M. B. M. (1986). Ehya' Olum Al-deen (Revival of Relegion Sciences) (3rd ed.). Beirut: Dar Al-Hikma.

Al-Ghazali, M. B. M. (1986). Mizan Al-’Amal (Work scales). Beirut: Dar Al Hikma.

Al-Ghazali, M. I. M. (1934). Al-Jawaher Al-Ghawali Min Ras'el Al-Imam Al-Ghazali (The precious jewels from Al-Imam Al-Ghazali epistles) (1st ed.). Cairo: Mohie Al-deen Sabri Alkurdi.

Al-Ghazali, M. I. M. (1970). Al Qusur Al-'Awali Fi Ras'el Al-Imam Al-Ghazali (The high palaces in Al-Imam Al-Ghazali epistles) (Vol. 1 \& 2). Cairo: Maktabet Al-Jondy.

Al-Ibrashi, M. A. (1969). Al-Tarbiyah Al-Islamiyya w Falaasifatuha (Islamic education and its philosophers) (1st ed.). Cairo: Library of Issa Al-Babi Al-Halabi and Partners.

Al-Kilani, M. E. (1978). Tatawwor Mafhoum Al-Nathariyya Al-Tarbawiyya Al-Islamiyya (The development of the Islamic educational theory). Amman: Jam'eyyat Ommal Al-Matabe’ Al-Ta’awuniyya.

Al-Qushayri, A. A. Q. (1990). Al-Resaala Al-qushayriyya Fi'ilam Al-Tasawwof (Al-Qushayri epistle in Sufism) (2nd ed., revised by Ma’rof Zarbaq and Ali Abed Alhameed Balta Je.). Beirut: Dar El-Jeel.

Al-Rashdan, A. (2004). Al-fikr Al-tarbawi Al-islaami (Islamic educational thought) (1st ed.). Amman: Dar Wa'al lil-nasher w Tawzee'.

Al-Sahrordi, A. A. B. A. (1966). Awaref Al-Ma'aref (Knowledge of sciences) (1st ed.). Beirut: Dar Alkitab Alarabi.

Barakeh, A. A. A. (1983). Fi Al-Tasawwof Wal Akhlaq: Dirasaat wa Nusus (In Sufism and Morals: studies and texts) (1st ed.). Kuwait: Dar Al-qalam.

Hasan, A. F. (1947). Mabaadi' fi Al-Tarbiya Al-Islaamiyya (Principles in Islamic education). Cairo: Matba’at lajnat Alta’alef wal Tarjama Wal Nashr.

Ibn, M. (1981). Tahtheeb Al-Akhlaaq wa Tat'heer Al-A'raq (Discipline of morals and ethnic cleansing). Beirut: Dar Al-kutub Al-ilmiyyeh.

Ibrahim, H. (2012). Al-Imam Al-Ghazali’s moral education. In Diraasaat islaamiyyeh (Islamic studies) (4th ed., pp. 176-154). AL Khartoom University.

Kheisha, Abd Al-M. Abd Al-G. (1991). Tahtheeb Al-akhlaq fil Islam (Morals discipline in Islam). Cairo: Dar Al-thaqafa Al-Arabiyya.

Khisha, A. A. M. A. G. (1991). Tahtheeb al-akhlaqfil Islam (Morals discipline in Islam).Cairo: DarAl-thaqafa Al-Arabiyya.

Miqdad, Y. (2003). Al-Tarbiya Al-Akhlaqiyya Al-Islamiyya (Islamic moral education) (3rd ed.). Al-Riyadh: The World of Books Library.

Mubarak, Z. (1988). Al-Akhlaq 'Ind Al-Ghazali (Al-Ghazali’s concept of morals) (1st ed.). Beruit: Al-Jeal Library.

Nassar, S. (1998). Madkhal ila Tatawwor Al-Fikr Al-Tarbawi (An introduction to the development of educational thought). Kuwait: Manshurat That Al-Salasel.

Yaldgen, M. (2003). At-tarbiya al-akhlaqiyya fi al-Islam (Morals and manners in Islam). Al-Riyad: Daar 'alam al-kutub. 